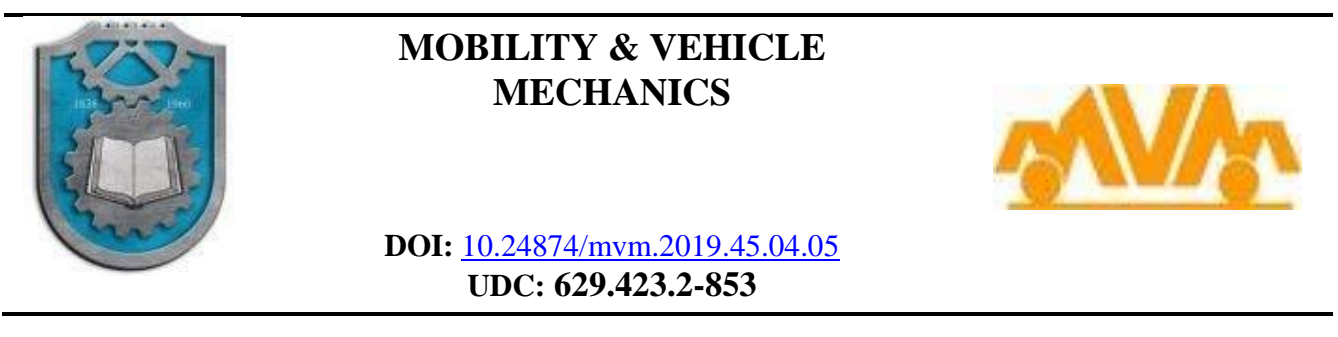

\title{
AN INDICATORS BASED APPROACH TOWARDS DECISION MAKING AND POLICY MAKING REGARDING INTRODUCING ELECTRIC VEHICLES
}

\author{
Kjosevski Stevan ${ }^{1 *}$, Kochov Atanas ${ }^{2}$, Kostikj Aleksandar ${ }^{3}$
}

Received in September $2018 \quad$ Accepted in April 2019

\section{RESEARCH ARTICLE}

\begin{abstract}
The dynamic development of the societies and cities is significantly based on the role of transport. That means a number of issues need to be addressed in order to reduce emission, keep traffic noise on acceptable level, increase energy efficiency and mitigate long-term threats. One of the solutions is the implementation of electric and hybrid cars. This problem can be solved thanks to the sustainable mobility concept, in which transport needs are limited at the stage of planning spatial development from one side or in implementation of solutions based on electric \& hybrid cars. This leads toward research for defining the indicators which would provide information to the policy makers for creating solutions for sustainable transportation and environmental protection. One of the scientific methods used in the research conducted in 6 Western Balkan countries is the AHP methodology and multi criteria decision making process for defining four pillars of indicators, social, economic, cultural, environmental indicators for possible implementation of different types of cars toward the fulfillment of the sustainability goals for the region of WBC's. WBC's as developing countries are still on the first stage in the process of defining indicators for policy making based on scientific methodology.
\end{abstract}

KEY WORDS: sustainable development, transport, electric vehicle, indicator, policy

C 2019 Published by University of Kragujevac, Faculty of Engineering

\footnotetext{
${ }^{1}$ Kjosevski Stevan, Assistent, University Mother Theresa, Blvd. Goce Delcev 9, 1000, Skopje, R. Macedonia, stevan.kjosevski@gmail.com (*Corresponding author)

${ }^{2}$ Kochov Atanas, PhD prof., University "Ss. Cyril and Methodius", Faculty of Mechanical Engineering, Karpos II b.b.P.O.Box 464, Skopje, R. Macedonia, atanas.kochov@mf.du.mk

${ }^{3}$ Kostikj Aleksandar, Assoc. prof., University "Ss. Cyril and Methodius" in Skopje, Faculty of Mechanical Engineering, Blvd. Goce Delcev 9, 1000, Skopje, R. Macedonia, aleksandar.kostikj@mf.du.mk
} 
This paper presents the scientific approach towards decision-making and policy creation for introduction of electric vehicles. The first step, identification of indicators, suitable for the electric vehicles, and developing countries region, has been taken. The paper shows a proposal for indicators on a state/region level, but also such list for personal/company need. The list of indicators is prepared based on wide and deep references analysis, and also on view of big number of experts in the region.

\section{PRISTUP ZASNOVAN NA INDIKATORIMA U ODLUČIVANJU I DONOŠENJU POLITIKE U POGLEDU UVOĐENJA ELEKTRIČNIH VOZILA}

REZIME: Dinamički razvoj društva i gradova značajno se zasniva na ulozi saobraćaja. To znači da treba rešiti brojna pitanja kako bi se smanjila emisija, održala buka u saobraćaju na prihvatljivom nivou, povećala energetska efikasnost i ublažile dugoročne pretnje. Jedno od rešenja je primena električnih i hibridnih automobila. Ovaj problem se može rešiti zahvaljujući konceptu održive mobilnosti, u kome su potrebe za transportom ograničene $u$ fazi planiranja prostornog razvoja sa jedne strane ili primene rešenja koja se zasnivaju na električnim i hibridnim automobilima. Ovo vodi ka istraživanju definisanja indikatora koji bi kreatorima politika pružili informacije o stvaranju rešenja za održivi transport i zaštitu životne sredine. Jedna od naučnih metoda koja se koristi u istraživanju sprovedenom u 6 zemalja Zapadnog Balkana ( eng. WBC - Wastern Balkan countries) je AHP metodologija i višekriterijumski postupak odlučivanja za definisanje četiri stuba indikatora, socijalnih, ekonomskih, kulturnih, ekoloških pokazatelja za moguću primenu različitih vrsta automobila prema ispunjenju održivosti ciljeva za region WBC's. WBC kao zemlje u razvoju još uvek su u prvoj fazi procesa definisanja pokazatelja za kreiranje politike zasnovane na naučnoj metodologiji. Ovaj rad predstavlja naučni pristup odlučivanju i kreiranju politike za uvođenje električnih vozila. Prvi korak je identifikacija pokazatelja, pogodnih za električna vozila i region zemalja u razvoju. U radu je prikazan predlog indikatora na nivou države/regiona, ali i takav spisak za lične potrebe preduzeća. Lista pokazatelja se priprema na osnovu široke i dubinske analize referenci, kao i na uvidu velikog broja stručnjaka u regionu.

KLJUČNE REČI: održivi razvoj, transport, električno vozilo, indikator, politika 


\title{
AN INDICATORS BASED APPROACH TOWARDS DECISION MAKING AND POLICY MAKING REGARDING INTRODUCING ELECTRIC VEHICLES
}

\author{
Kjosevski Stevan, Kochov Atanas, Kostikj Aleksandar
}

\section{INTRODUCTION}

The world is increasingly talking about sustainable development in the broadest sense and makes efforts to reach it. Transport is one of the largest economic branches globally. This sector has strong impacts on the three main pillars of sustainable development: economic, social and environmental. Also, in accordance with the current trends, it is projected to double the world population of motor vehicles over the next twenty years, and as a consequence, an increase in energy consumption in all regions is expected globally. Knowing that fossil fuels are finite resources and will be exhausted, as well as the need of reduced emissions due to pollution, solutions have been found in the implementation of electric and hybrid vehicles. The need of research for defining indicators to help policy makers create solutions for sustainable transport and environmental protection came to life. The scientific method used in the research is the AHP method and multi criteria decisionmaking process for defining the main pillars of indicators: economic, social and environmental. Taking into account that the WBC's are developing countries, the identification of the indicators for implementation of electric and hybrid vehicles has been made. The indicators are made to fill the needs on state and regional level as well as for personal and company use. For their use, it is necessary to build a personal and institutional capacity that would guarantee the reduction of risks in making important, costly and farreaching decisions.

\section{METHODOLOGY FOR DECISION-MAKING}

Making decisions is a complex process that can have far-reaching positive or negative consequences. It is a process of choosing an alternative, from a group of alternatives, in a systematic and logical way. This is why this process has been and is the subject of many scientific researches that result in various methodologies.

\subsection{Process of decision making}

Making a decision is a process of choosing an alternative, from a group of alternatives, in a systematic and logical way. The basic step by step process used in decision making is called the decision-making process. 


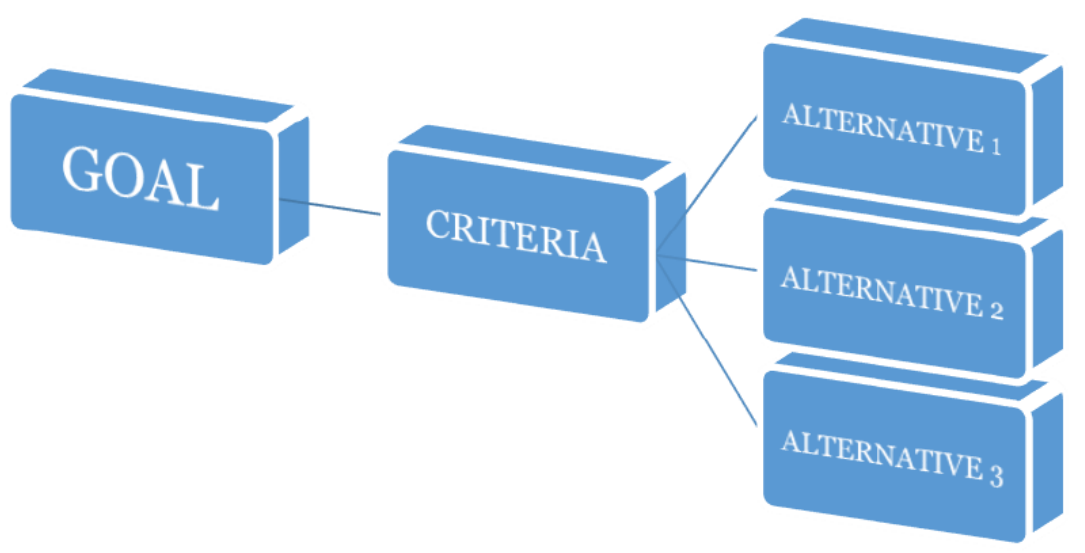

Figure 1. Basic diagram of decision making

The individual steps, as shown in Figure 1, are:

1. Defining the decision-making problem (goal)

2. Identification of criteria

3. Determining the alternatives, etc.

Depending on the type of problem to be decided, there are two types of decision: decision making based on a single criterion and decision-making based on multiple criteria. A decision-making based on multiple criteria is often referred to as Multi Criteria Decision Making - MCDM, [2].

\subsubsection{The AHP method}

The AHP method is based on the experience of its inventor T.L. Saaty. It is developed in response to the realization that there is a great lack of a general method that is easy to understand and apply, which will allow making complex decisions. Since then, the simplicity and power of AHP has led to its wide application in many domains in every part of the world. AHP has found applications in businesses, governments, social studies, research and development, defence and other areas that involve decisions that require choice, priority, and prediction, [3]. Basically, AHP helps to structure the complexity, measurement, and synthesis of the ranking. These features make it suitable for a wide range of applications. AHP has been tested as theoretically clear, tested on the market and accepted methodology. Its almost universal scalability as a new paradigm for decision making, along with its easy application and understanding make up its success. Moreover, it proved to be capable of yielding results that are consistent with perceptions and expectations.

\section{ANALYSIS OF THE CURRENT STATE IN THE WESTERN BALKANS REGION AND DEFINING ITS PROBLEMS}

The Western Balkan region covers countries that are not members of the European Union, which at the same time, in the majority, are candidates for its members. In the direction of efforts to become EU members, the countries of the Western Balkans must accelerate their development in a sustainable way. Therefore, the postulates and the mechanisms of sustainable development must be mastered and implemented. Transport, as one of the main 
An indicators based approach towards decision making and policy making regarding introducing electric vehicles

components of development, must also be sustainable. The significance of transport is great, not only in the economic pillar but also in the other two main pillars of sustainable development: social and environmental. In this process, politics (governance) and planning have a lot of significance in the process, and more recently the significance of culture which in the region of the Western Balkans brings a series of specifics in relation to that of the older EU members. The countries of the region are conditioned to implement this process and accelerate it in a period of intense technical and technological innovation. Electric vehicles are one of the most typical examples of a complex challenge, given that they are in the middle of multiple pillars of the sustainable development of countries. This arises from several key aspects that are particularly relevant for this region, which by their nature are included in the four groups of SWOT analyses as show in the table below (Table 1).

Table 1. SWOT analysis of the state of transport in the Western Balkans region

\begin{tabular}{|c|c|}
\hline Strengths (advantages) & Weaknesses (constraints) \\
\hline $\begin{array}{l}\text { Road transport, and especially passenger transport, } \\
\text { are the dominant segments of the economy and } \\
\text { mobility } \\
\text { Electric vehicles are environmentally superior } \\
\text { - The performance of electric vehicles continuously } \\
\text { improves } \\
\text { - The offer of electric vehicles is improving }\end{array}$ & $\begin{array}{l}\text { - The percentage of new vehicles is small compared to } \\
\text { the total number of registered vehicles } \\
\text { - Electric vehicle prices are too high compared to } \\
\text { conventional ones } \\
\text { - There are no plans for development of transport in } \\
\text { which the potential of electric vehicles is clearly } \\
\text { elaborated, as well as strategies for their introduction } \\
\text { - It is not clear the connection between the needs and } \\
\text { the possibilities of the power system to support the } \\
\text { development of a system from fillers } \\
\text { - There are no national strategies for the development of } \\
\text { - Thectric chargers } \\
\text { - There are no national fleet renewal strategies } \\
\text { - Thout ecology } \\
\text { - There is no research on the perception of electric } \\
\text { vehicles by potential buyers }\end{array}$ \\
\hline Occasions & Threats \\
\hline $\begin{array}{l}\text { - Large proportion of the population gravitates towards } \\
\text { the major urban centers, where most of the economic } \\
\text { activities } \\
\text { - Large part of the urban transport takes place with } \\
\text { passenger vehicles } \\
\text { In recent years there has been a rapid increase in the } \\
\text { number of registered vehicles } \\
\text { The condition with the fillers is such that there are only } \\
\text { sporadic efforts to place in a limited number of } \\
\text { separate locations } \\
\text { The age structure of the vehicle is extremely } \\
\text { unfavorable } \\
\text { The level of pollution in urban areas is, as a rule, one } \\
\text { of the highest in Europe } \\
\text { The post-sales support of electric vehicles has not yet } \\
\text { been built and so on. }\end{array}$ & $\begin{array}{l}\text { - In recent years there has been a rapid increase in the } \\
\text { number of registered vehicles } \\
\text { Most of the re-registered vehicles are used with low } \\
\text { emission characteristics } \\
\text { - A very small proportion of new vehicles are hybrid, an } \\
\text { even smaller number are plug-in hybrids, and the } \\
\text { smallest number are electric } \\
\text { The condition with the fillers is such that there are only } \\
\text { sporadic efforts to place in a limited number of } \\
\text { separate locations } \\
\text { The age structure of the vehicle is extremely } \\
\text { unfavorable } \\
\text { The level of pollution in urban areas is, as a rule, one } \\
\text { of the highest in Europe }\end{array}$ \\
\hline
\end{tabular}

\subsection{Choosing a scientific research method}

The previous chapter of this paper provides a description of the theoretical foundations of multi-criteria decision-making methods. Given that this is a method that will be applied in the field of transport, an additional literature analysis was made, which led to the conclusion that good results from the use of the AHP method can be expected. In the part of the calculations according to the AHP method, several approaches are possible. It can be done with classical calculations, or by using certain software tools, starting from Excel, to special program packages. This research uses the Expert Choice software package. There are more reasons for this. Among them is its availability and the already existing local experience. There are also numerous sources with examples that indicate the compatibility of this software package with the AHP method Expert Choice, with its adaptability to the user, certainly has a great contribution to the success of the AHP method. It includes intuitive user interfaces, automatic calculation of priorities and inconsistency, and several ways to conduct sensitivity analysis. 


\subsection{Defining Indicators and determining alternatives}

The chosen method of research relies on recognizing and selecting indicators. Typically, the stage of choosing the indicators begins with a thorough search of literature. Broadly speaking, the number of papers that in this way analyses sustainable development is very large. Usually, the minimum number of indicators encountered is eight, and the maximum eighty-seven. The average is about twenty-eight indicators. These indicators are mainly divided into segments: economic, social, ecological and institutional, etc [4]. From the analysed literature a selection of nine literary sources was made, which in their completeness and specifics are in direct relation to the topic of the research. From all of them, by analysis and filtering, are extracted the most relevant from a large number of indicators and are organized into groups according to their similarity. In accordance with the AHP method and the way the Expert Choice software package works, it is necessary to choose alternatives whose influence will be analysed in the light of the selected indicators. At the current level of the development of automotive technology, the supply of the market and the presence of vehicles in the traffic, the following alternatives of means of transport were selected:

- Alternative A1: electric vehicles

- Alternative A2: plug-in hybrid vehicles

- Alternative A3: hybrid vehicles

- Alternative A4: vehicles with alternate fuel

- Alternative A5: vehicles with petrol engines

- Alternative A6: vehicles with diesel engines

With the alternatives listed, further research was carried out.

\section{USABILITY OF THE RESULTS}

\subsection{Indicators that can serve to make decisions in the context of the use of electric vehicles}

When compiling the list of indicators and their hierarchical placement in the questionnaire that conducted the experimental examination, it started from a thorough review of the literature, with the intention not to make special focus or exclusion of some of them [1]. The consistency and robustness of the results obtained in the ambient of a number of indicators and alternatives, together with the applied scientific method for multi-criteria decision making, make the results of this research more useful in many ways. Their use is possible for making policy assessments from the perspective of central or local government, planning and making corporate, family or personal decisions when purchasing vehicles and the like. If a list of indicators for a narrower and more specific group of respondents is required, or if the need for a decision concerns a number of aspects and alternatives, it is also possible to produce a list of indicators for such a purpose. As a result of the narrowing of the volume of interest, the number of indicators, probably the number of hierarchical levels, will be reduced, and certain indicators will be shifted along the levels. In the area of sustainable transport, in the light of the use of electric vehicles, the number of papers is very limited. Therefore, the identification and selection of research indicators in this context has been accessed in the manner described below. From the analysed literature, a selection of nine literary sources was made, which in their completeness and specifics are in direct relation with the topic of the research. All of them, by analysis and filtering, extracted the most relevant from a large number of indicators and are organized into groups according to their similarity. Then, "condensation, i.e. compression" of similar indicators was made, with more 
than the literally determined ones being replaced by one. In addition to the indicators that are taken from the literature, indicators are defined and presented, which, according to the techno-economic, social and other aspects, are specific for the use of electric vehicles. Here, above all, is a more detailed expression of individual indicators in order to express the specifics of the particular research. Thus, in the economic indicators are treated the price of vehicles, the costs for their exploitation (range of movement performance) and maintenance, the infrastructural aspects related to the conditions for charging electric vehicles and similar. The group of social indicators detail the elements related to the suitability of passenger vehicles for users with special needs, then the impact of obstacles such as noise and the like. In the ecological group of indicators, adjustments are made according to the structure of the emissions of individual alternative vehicles, noise etc. For the first time (within the information derived from the analysed literature), the alternatives in the column of indicators called culture were made, [1].

Overview of the indicators from the literature and the chosen indicators is shown below:

1. From literature:

- $\quad$ minimal number of indicators is 8

- $\quad$ maximal number of indicators is 87

- $\quad$ average number of indicators is 28 .

2. Chosen:

- $\quad$ total number of indicators is 90

- number of hierarchy levels is 5

- indicators at the first hierarchical level: economic, social, environmental, good governance and planning and culture.

The chosen indicators can be used for policy-making as well as decision making on national as well as regional level. Due to overcompensation these indicators are not presented, but are available in the reference number 1.

If a list of indicators for a narrower and more specific group of respondents is required, or if the need for a decision refers to a smaller number of aspects and alternatives, it is also possible to produce a list of indicators for such a purpose. As a result of the narrowing of the volume of interest, the number of indicators, probably the number of hierarchical levels, will be reduced, and certain indicators will be shifted along the levels. Potential examples of the specific scope of the analysis:

1. Analysis of the needs for conducting economic and environmental policies by central or local government;

2. analyses for the needs of making business decisions in the business segment (corporate decisions)

3. analyses for the needs of making personal or family decisions.

As an example of preparing such a separate list of indicators, Table 2 shows a list that could be used in the variant 3 . 
Table 2. List of indicators that can be used for making personal and family decisions when procuring a new vehicle in the context of sustainable development

\begin{tabular}{|c|c|c|c|}
\hline Level & 1 & 2 & 3 \\
\hline \multirow{15}{*}{ Economic } & \multirow[b]{2}{*}{ Vehicle prices } & Price of a new vehicle & \\
\hline & & $\begin{array}{l}\text { Price of second-hand } \\
\text { vehicle }\end{array}$ & \\
\hline & \multirow{2}{*}{ Type of transport } & Urban & \\
\hline & & Suburban & \\
\hline & \multirow{2}{*}{ Performance } & Rank / autonomy & \\
\hline & & Dynamic characteristics & \\
\hline & $\begin{array}{l}\text { Density of electric charging } \\
\text { stations / fuel pumps per km }\end{array}$ & & \\
\hline & \multirow{3}{*}{ Parking } & Public & $\begin{array}{l}\text { With / without electric } \\
\text { charging stations }\end{array}$ \\
\hline & & Private & $\begin{array}{l}\text { With / without electric } \\
\text { charging stations }\end{array}$ \\
\hline & & Work & $\begin{array}{l}\text { With / without electric } \\
\text { charging stations }\end{array}$ \\
\hline & \multirow{3}{*}{ Costs for using a vehicle } & Tolls, parking, etc. & \\
\hline & & Environmental tax & \\
\hline & & Maintenance & \\
\hline & Price of fuel / electricity & & \\
\hline & Costs for capital maintenance & & \\
\hline \multirow{3}{*}{ Social } & Mobility & $\begin{array}{l}\text { Length and frequency of } \\
\text { travel }\end{array}$ & \\
\hline & $\begin{array}{l}\text { Need for management of a person } \\
\text { with special needs }\end{array}$ & & \\
\hline & $\begin{array}{l}\text { Health disorders with exposure to } \\
\text { emission and noise }\end{array}$ & & \\
\hline \multirow{2}{*}{ Environmental } & Technical level & & \\
\hline & Emission properties of the vehicle & & \\
\hline
\end{tabular}

\section{CONCLUSIONS}

The experiences from the conducted research and the results obtained in its separate phases allow for the conclusion of several conclusions, as well as perceiving the needs and directions for further research. Sustainable development and, within that framework, sustainable transport are not only concepts, but also messages for the present and future generations in order to preserve what is inherited from nature and to continuously improve the quality of life of the present and future generations. The literature, as well as numerous documents in this area, are a good basis for further efforts to achieve sustainable transport, and hence sustainable development. Fossil fuels have limited resources and the result of their use is a major contribution to the road vehicles to the air pollution and the environment as a whole. The use of electric vehicles, accompanied by their technical advancement and the development of plug-in hybrids, gives new hope that they can represent an alternative that is more likely to support the development of sustainable transport, that is, sustainable development in the broadest sense. Scientifically based methods for multi-criteria decision making, developed in recent decades, already have validated applicability in different conditions. The AHP method used in this test shows a high level of flexibility and adaptability to the task set. The analysed scenarios for supporting the use of electric vehicles make it possible to assess the potential effect of the usual measures that should also be complex and of a different nature. 
An indicators based approach towards decision making and policy making regarding

\section{REFERENCES}

[1] Kjosevski, S.: "Decision-making and policy to introduce electric vehicles as a contribution to regional sustainable development", $\mathrm{PhD}$ thesis, 2018, Skopje, Republic of Macedonia.

[2] Gade, P.K., Osuri, M.: "Evaluation of Multi Criteria Decision Making Methods for Potential Use in Application Security”, Master Thesis, Electrical Engineering, School of Computing, Blekinge Institute of Technology, Karlskrona, Sweden, 2014.

[3] Saaty, T.L.: "Decision making with the analytic hierarchy process", International Jurnal Services Sciences, Vol. 1, No. 1, 2008, pp 83-98.

[4] Buzási, A., Csete, M.: "Systainability Indicators in Assessing Urban Transport Systems", Periodica Polytechnica Transportation Engineering, Vol. 43, No. 3, 2015, pp 138-145. 